\title{
Levocabastine Hydrochloride
}

National Cancer Institute

\section{Source}

National Cancer Institute. Levocabastine Hydrochloride. NCI Thesaurus. Code C47582.

The hydrochloride salt form of levocabastine, a synthetic piperidine derivative with antihistaminic properties. Levocabastine is a second generation histamine-1 receptor antagonist. When applied locally to the eye as a topical solution, this agent reduces itching, rhinorrhea, and symptoms of allergic rhinitis or conjunctivitis. 